\title{
Statistical Distributions of Lightning Currents Associated With Upward Negative Flashes Based on the Data Collected at the Säntis (EMC) Tower in 2010 and 2011
}

\author{
Carlos Romero, Farhad Rachidi, Fellow, IEEE, Mario Paolone, Senior Member, IEEE, and \\ Marcos Rubinstein, Senior Member, IEEE
}

\begin{abstract}
This paper presents statistical distributions of lightning current parameters based on the lightning current and current-derivative waveforms measured at the Säntis Tower site in 2010 and 2011. The total number of flashes analyzed in this study was 167 , which includes nearly 2000 pulses. The statistical distributions refer to upward negative flashes. It is shown that negative flashes are mainly concentrated in the summer months during the convective season. Statistical data on the salient lightning current parameters, namely, peak current, peak current derivative, risetime, pulse charge, pulse duration, interpulse interval, and flash multiplicity are presented and discussed. The obtained data that constitute the largest dataset available to this date for upward negative flashes are also compared with other available statistical distributions.
\end{abstract}

Index Terms-Instrumented tower, lightning current, statistical distributions, upward flashes.

\section{INTRODUCTION}

$\mathbf{T}$ HE KNOWLEDGE of the lightning channel-base current waveforms is of primary importance for the analysis of lightning interaction with electrical power and electronic systems as well as for the design of relevant protections.

Lightning channel-base current waveforms are obtained either by direct measurements using instrumented towers (e.g., [1]-[5]) or from artificially-initiated lightning (e.g., [6]-[8]). Estimates of various lightning current parameters can also be obtained from the measurements of lightning electromagnetic fields assuming one or more empirical [9] or theoretical [10], [11] relations between the lightning current and associated electromagnetic fields.

In this paper, we present statistical data on lightning current parameters associated with upward negative flashes obtained

Manuscript received November 06, 2012; revised January 24, 2013; accepted March 05, 2013. Date of current version June 20,2013. This work was supported by the Swiss National Science Foundation (Project No. 200021-122457). Paper no. TPWRD-01202-2012.

C. Romero, F. Rachidi, and M. Paolone are with EPFL, Lausanne 1015, Switzerland (e-mail: carlos.romero@epfl.ch; farhad.rachidi@epfl.ch; mario.paolone@epfl.ch).

M. Rubinstein is with HEIG-VD, Yverdon 1400, Switzerland (e-mail: marcos.rubinstein@heig-vd.ch).

Color versions of one or more of the figures in this paper are available online at http://ieeexplore.ieee.org.

Digital Object Identifier 10.1109/TPWRD.2013.2254727 using directly-measured current and current derivative waveforms in 2010 and 2011 at the Säntis Tower in Switzerland. The tower was instrumented in 2010 [12], [13]. The period of analysis extends from May 2010 to January 2012. Out of a total of 200 successfully recorded flashes, 167 were of negative upward type. The analysis presented in this paper concerns upward negative flashes. Data on positive and bipolar flashes will be presented in a subsequent publication. Reference is also made to available statistical distributions.

Upward flashes are of interest for lightning protection of tall structures such as telecommunications towers. Additionally, upward flashes are considered to be a major threat for modern wind turbines that are characterized by very long blades and tall masts with overall heights that usually exceed a $100 \mathrm{~m}$. As a result, the majority of the strikes to modern turbines are expected to be upward lightning [14].

The paper is organized as follows: Section II describes the Säntis tower and the installed instrumentation. Section III describes the methods used to characterize lightning current parameters, as well as the algorithms used to post-process the measured lightning current waveforms to infer their relevant characteristics. Section IV presents the statistical analysis of the lightning current parameters. Finally, a summary and conclusions are presented in Section V.

\section{SÄNTIS TOWER AND ITS INSTRUMENTATION}

The Säntis Tower (Fig. 1) is a 124-m-tall tower sitting on

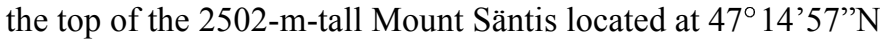
and $9^{\circ} 20^{\prime} 32^{\prime \prime} \mathrm{E}$ in the Appenzell region in the northeast of Switzerland. The grounding resistivity in the Säntis Mountain area (rocky soil) is in the order of $10 \mathrm{k} \Omega \mathrm{m}$. The tower has a hollow, metallic inner conical structure of $2 \mathrm{~m}$ radius at the base and $1 \mathrm{~m}$ at its top. An outer Plexiglas structure has a radius of $3 \mathrm{~m}$ at the base and $1.5 \mathrm{~m}$ at the top. The structure serves mainly as a telecommunications tower and as a weather station. A decade-long analysis on the lightning incidence to several towers at various locations in Switzerland resulted in the choice of the Säntis tower, which is struck by lightning about 100 times a year [13].

The Säntis station has been instrumented using advanced and modern equipment including remote monitoring and control capabilities for an accurate measurement of lightning current parameters [13], [15]. The lightning current is measured at two 


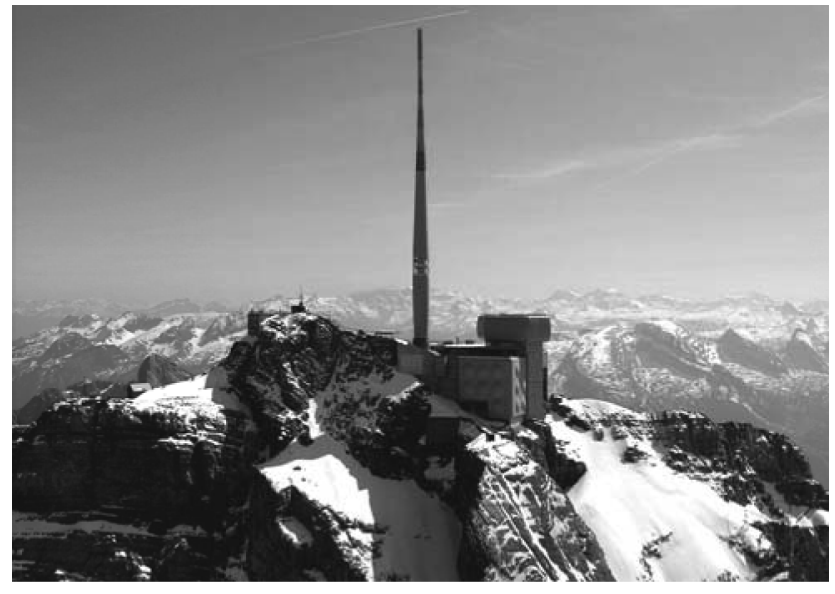

Fig. 1. Säntis tower.

different heights, $24 \mathrm{~m}$ and $82 \mathrm{~m}$. At the lower height, we installed two Rogowski coils with different sensitivities, each one with its analog integrator used to obtain the current waveform. These Rogowski sensors were manufactured, respectively, by PEM Inc. and ROCOIL. Two further sensors were installed at $82 \mathrm{~m}$. The first one is a Rogowski coil (PEM Inc.) coupled with its analog integrator. The second sensor placed at that height is a specially-designed multi-gap magnetic loop (B-Dot) sensor. It has been specifically developed to measure the lightning current derivative [16]. The analog outputs of the sensors are relayed to a digitizing system by means of analog-to-digital-digital-to-analog 12-bit optical links characterized by an overall bandwidth from dc to $25 \mathrm{MHz}$. The maximum measurable current level with the PEM Rogowski coils is $120 \mathrm{kA}$ and the maximum measurable current derivative with the B-Dot sensor is $400 \mathrm{kA} / \mathrm{is}$. The PEM Rogowski coil located at $82 \mathrm{~m}$ is characterized by a frequency response ranging from $50 \mathrm{mHz}$ to 2.4 $\mathrm{MHz}$, while the upper frequency limit of the B-Dot sensor is about $20 \mathrm{MHz}$ (for more details, see [16]). The measurement window for each flash is $1.2 \mathrm{~s}$ with a pre-trigger delay of $0.25 \mathrm{~s}$ and a sampling frequency of $100 \mathrm{MHz}$. Each flash is triggered by the B-dot sensor and the trigger level is $2 \mathrm{kA} / \mu \mathrm{s}$.

The status and settings of each pair of sensors can be monitored and changed by means of a control system designed and built using National Instruments Compact-RIO modules linked via fiber optics using 100Base-FX Ethernet. A local server running monitoring and storage tasks is housed in a shielded control room several tens of meters from the base of the tower. The server and the front-end station are connected to the Internet over a router and a standard DSL link, allowing remote maintenance, monitoring, and control of the overall measurement chain. More details on the installed measurement system can be found in [13], [16].

\section{LIGHTNING CURRENT PARAMETERS CONSIDERED IN THIS STUDY}

\section{A. Current Waveform Associated With a Typical Upward Negative Flash}

Fig. 2 shows an example of a flash current record measured by one of the Rogowski coils located at the top measuring lo-

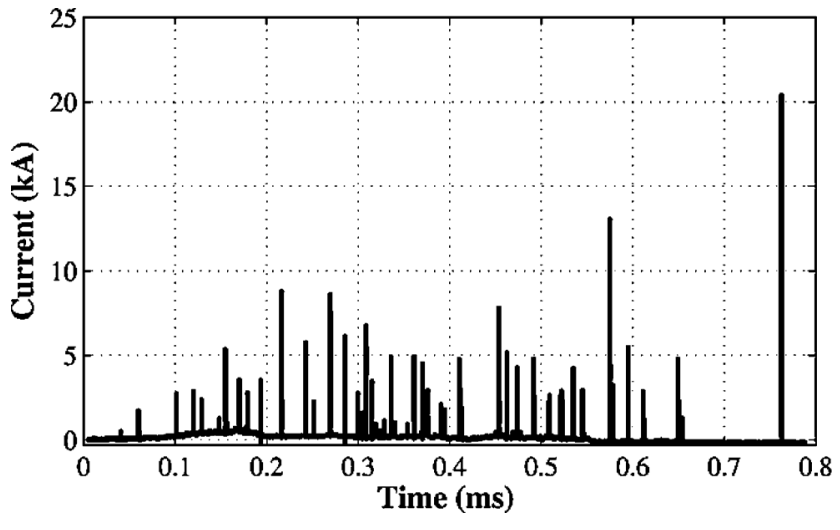

Fig. 2. Typical current waveform measured at the Säntis Tower using the Rogowski coil $82 \mathrm{~m}$ above ground level. The flash occurred on October 12, 2010, at $19 \mathrm{~h} 52$.

cation $(82 \mathrm{~m})$. The current waveform is typical of upward negative flashes with an initial continuous current (ICC) of about $500 \mathrm{~ms}$ duration, and superimposed ICC pulses. The number of recorded ICC pulses is in excess of 30, with peak amplitudes ranging from about $1 \mathrm{kA}$ to $14 \mathrm{kA}$. After the extinction of the ICC, a return stroke with a peak current of about $22 \mathrm{kA}$ can be distinguished. The maximum time derivative of the return stroke is about $56 \mathrm{kA} / \mu \mathrm{s}$ and the total transferred charge of this flash is $21 \mathrm{C}$.

For the statistical analysis of the parameters associated with current pulses, we considered together: 1) return stroke pulses, namely, pulses occurring after the extinction of the initial continuous current and 2) pulses superimposed on the initial continuous current fulfilling two conditions: a rise time lower than $8 \mu \mathrm{s}$ and an amplitude greater than $2 \mathrm{kA}$. These pulses are believed to be associated with the leader/return stroke mode of charge transfer, as opposed to slower pulses which are associated with the M-component charge transfer mode [17].

\section{B. Procedure for the Estimation of Lightning Current Parameters}

Measured lightning currents are characterized by a frequency spectrum extending from dc to a few megahertz [18]. Broadband resistive shunts (e.g., [5]) represent an ideal solution for the measurement of lightning currents as their output is a faithful reproduction of the current associated with various processes of a lightning discharge including, in the case of upward discharges, the initial continuous current, superimposed pulses, and return strokes. However, such a solution was not possible in the case of the Säntis Tower. Another solution often adopted for the measurement of lightning currents on instrumented towers is the use of Rogowski coils (e.g., on the CN Tower in Canada [19]). Rogowski coils can, in principle, have a frequency response down to the $\mathrm{Hz}$ or even $\mathrm{mHz}$ regions and they should be able to record initial continuing currents associated with upward flashes (i.e., [20]). However, their high frequency response is limited by the size of the sensor and by its resonance frequency, which might be as low as some hundreds of kilohertz [15]. As a result, the current rise time and time-derivative might be affected by the high frequency shortcomings of Rogowski coils. 


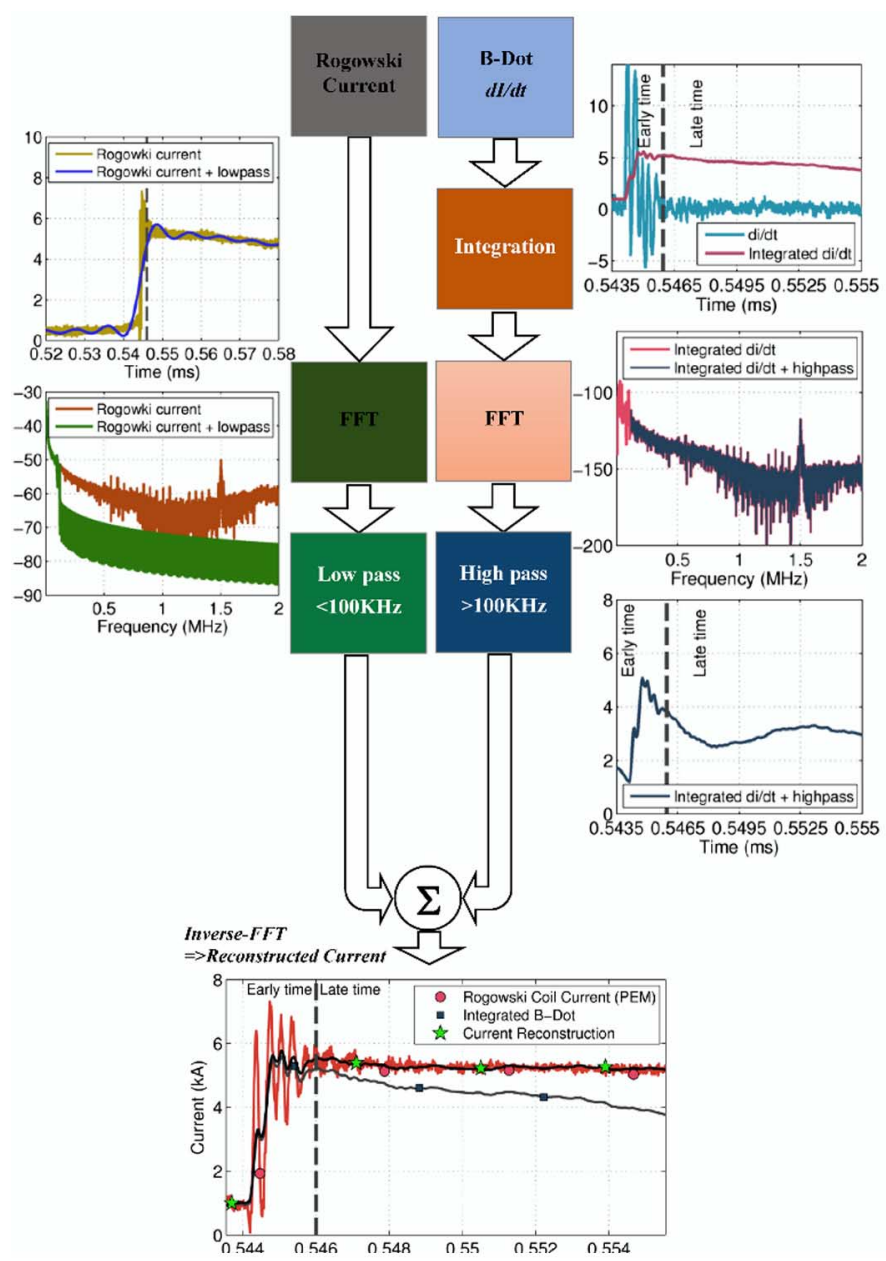

Fig. 3. Block diagram of the current reconstruction algorithm from the Rogowski coil and the B-dot sensor.

In order to overcome the limited high frequency response of the Rogowski coils, we used a multi-gap B-dot sensor which has been shown to be very accurate for the measurement of the early-time response of the current derivative [16]. Assuming proportionality between magnetic field and current, the current is obtained by numerical integration of the B-Dot sensor output. The effectiveness of the simultaneous use of Rogowski coils and B-dot sensors for the measurement of lightning currents was demonstrated through laboratory tests carried out in the high voltage laboratory of the Swiss Federal Institute of Technology, Lausanne (EPFL) [16].

An algorithm was developed and used for the reconstruction of the impulse current signal from the B-Dot and Rogowski signals (see the block diagram shown in Fig. 3).

One of the advantages of the developed measurement system is that all the signals are sampled in parallel as the adopted digitizers share the same trigger signal and have locked oscillators. As a consequence, we can apply subsequent filtering and superposition to signals coming from different sensors. In particular, the Rogowski coil signal is transformed into the frequency domain by applying an FFT and it is filtered using a $100 \mathrm{kHz}$ low-pass equal-ripple FIR filter. This low-pass filter removes the measured resonance frequency of the Rogowski coils $(1.2$ $\mathrm{MHz}[16])$. The B-dot sensor signal is integrated before being

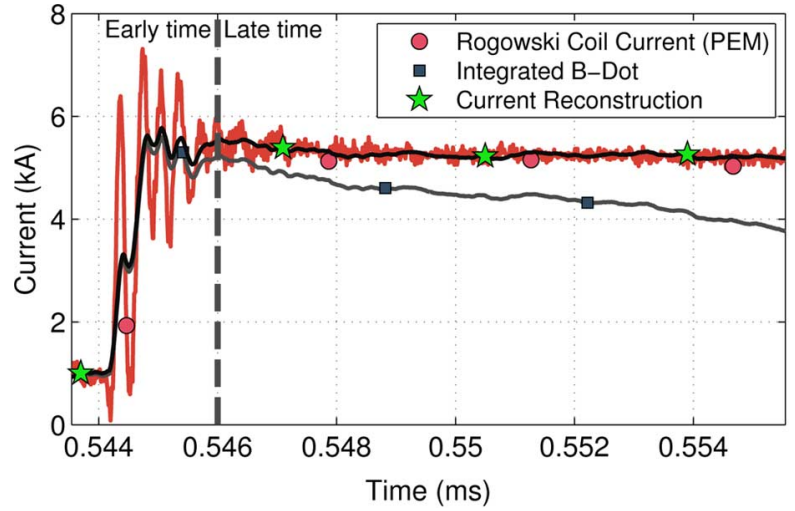

Fig. 4. Measured and reconstructed waveforms associated with a return stroke of an upward flash measured at Säntis. Dot markers: Current waveform measured by the Rogowski coil. Square markers: Current waveform obtained by numerical integration of the B-dot sensor. Star markers: Reconstructed waveform according to the procedure described in Fig. 3.

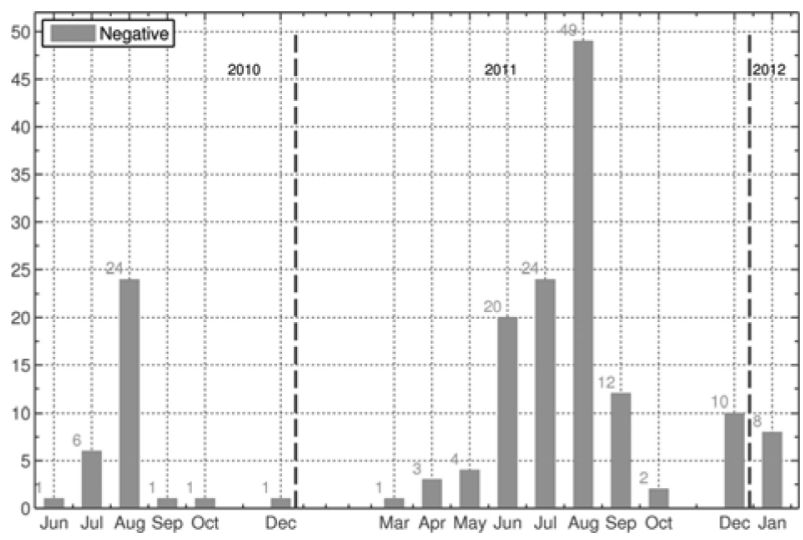

Fig. 5. Negative flash count to the Säntis tower. June 2010 to January 2012

transformed into the frequency domain and filtered using a 100 $\mathrm{kHz}$ high-pass filter. The two signals are then added and converted back into the time domain. This approach was tested using different waveforms measured simultaneously by the two systems and found to be very reliable. Fig. 4 shows an example of waveforms recorded by the Rogowski coil and the integrated B-dot sensor output associated with a return stroke in an upward negative flash on the Säntis Tower where it can be seen that the early-time response of the reconstructed current is essentially determined by the B-dot sensor as it does not show the oscillatory behaviour of the Rogowski coil which is presumably due to the coil resonance [15]. On the other hand, the late time behaviour of the reconstructed signal follows that of the Rogowski coil.

\section{STATisticAl ANALYSIS}

\section{A. Measured Data}

The presented statistical analysis concerns data recorded at the Säntis Tower from May 2010 until January 2012. Over this period, a total of 200 flashes were recorded, including 33 positive and bipolar flashes. Although for many of the flashes, the continuous current was not high enough to be discernible above the noise, we assumed all flashes to be of the upward type as it 


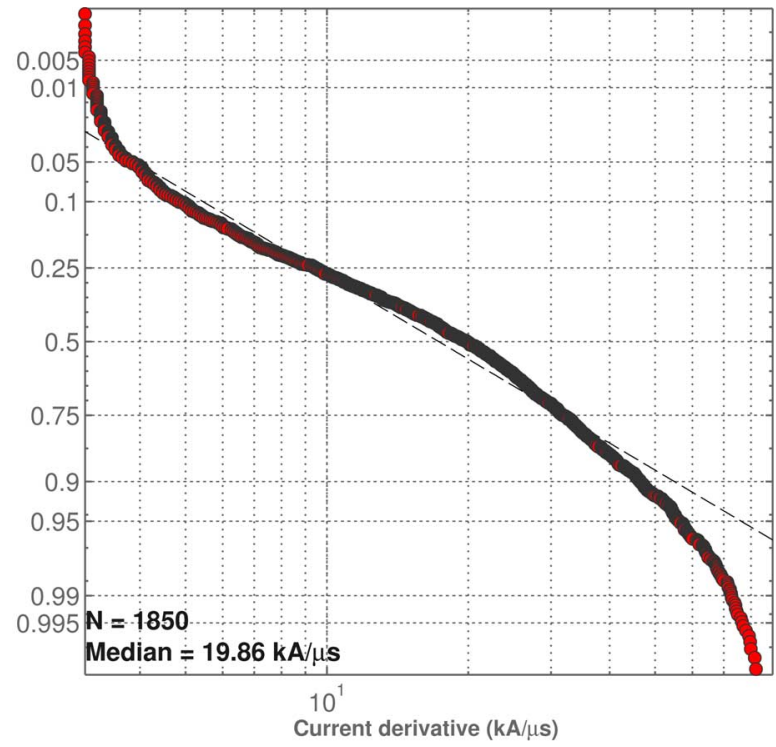

Fig. 6. Maximum current derivative probability plot.

TABLE I

Statistical Parameters of Peak Current Derivative

\begin{tabular}{|c|c|c|c|c|c|c|}
\hline \multicolumn{7}{|c|}{ Peak current derivative $(\mathrm{kA} / \mu \mathrm{s})$} \\
\hline \multirow[t]{2}{*}{ Tower } & \multirow{2}{*}{$\begin{array}{l}\text { Sample } \\
\text { size }\end{array}$} & \multicolumn{5}{|c|}{ Percentage $\frac{\text { Exceeding Tabulated }}{\text { Value }}$} \\
\hline & & $95 \%$ & $90 \%$ & $50 \%$ & $10 \%$ & $5 \%$ \\
\hline $\begin{array}{l}\text { Empire State } \\
\text { Building [21] }\end{array}$ & 71 & 1.2 & 2.5 & 13.0 & 33 & 38 \\
\hline $\begin{array}{c}\text { San Salvatore } \\
{[22]}\end{array}$ & 710 & - & 5.6 & 26 & 123 & - \\
\hline $\begin{array}{c}\text { Peissenberg } \\
{[23]^{*}}\end{array}$ & 125 & - & - & 11 & - & 87 \\
\hline CN Tower [19] & 387 & 3.8 & - & 18.8 & - & 37 \\
\hline $\begin{array}{l}\text { Säntis (This } \\
\text { study) }\end{array}$ & 1850 & 3.9 & 4.8 & 19.9 & 46.5 & 56.3 \\
\hline
\end{tabular}

is expected that a structure with the characteristics of the Säntis Tower be struck by upward lightning most or all of the time.

\section{B. Seasonal Occurrence of Flashes to the Säntis Tower}

Fig. 5 presents the monthly flash count spanned, and accumulated over the whole measurement period.

It can be seen from Fig. 5 that negative flashes are mainly concentrated in the summer months during the convective season, August being the month during which most of the negative flashes occurred ( 24 events in 2010 and 49 events in 2011). This distribution contrasts with the Gaisberg Tower measurements for which lightning strikes are quasiuniformly distributed over the year [5]. Note also the significant increase of the lightning activity in 2011 with respect to 2010 . We believe that the increase is essentially due to year-to-year weather variations. Indeed, MeteoSuisse measured a mean temperature of $8{ }^{\circ} \mathrm{C}$ on the Säntis for the month of August 2011, which is about $60 \%$ higher than the $4.8{ }^{\circ} \mathrm{C}$ mean temperature for the same month in 2010. Also, more than 50 flashes (positive and

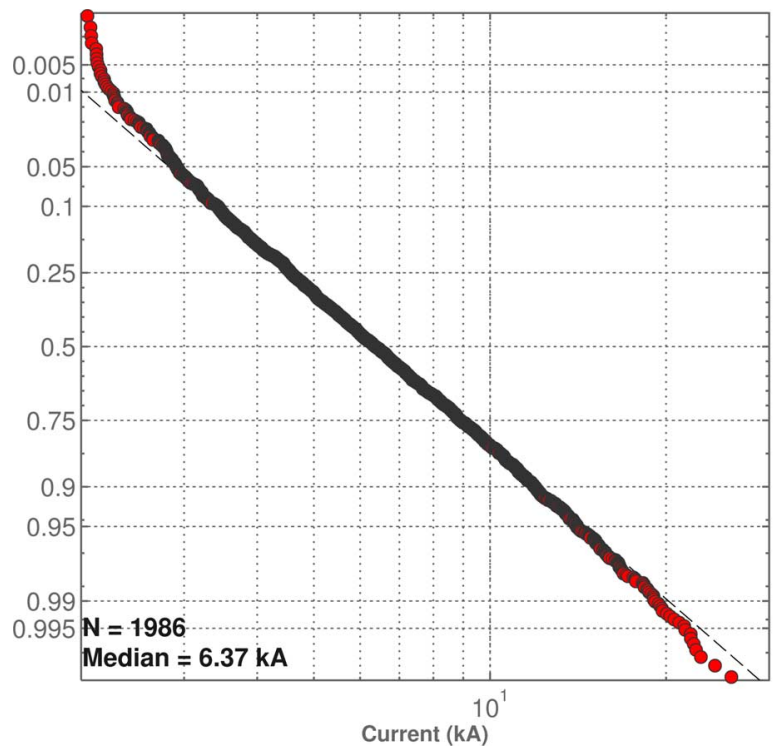

Fig. 7. Peak current probability plot.

TABLE II

Statistical Parameters of Peak Current

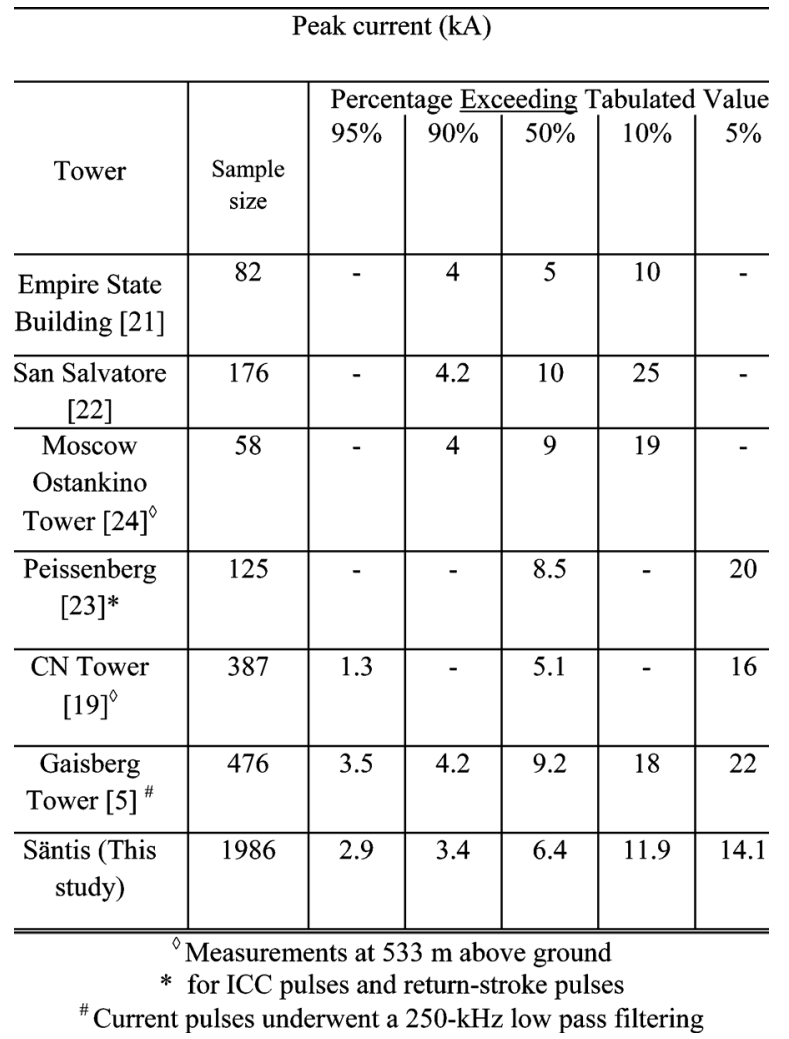

negative) were measured during one single storm occurred in the morning of August 27, 2011. Finally, some flashes might have been missed by our system during the first months of operation.

\section{Maximum Current Derivative}

As indicated in [15], the scaled B-dot sensor is directly used for the evaluation of the maximum current derivative statistical values. Fig. 6 presents the probability plot and histogram of 


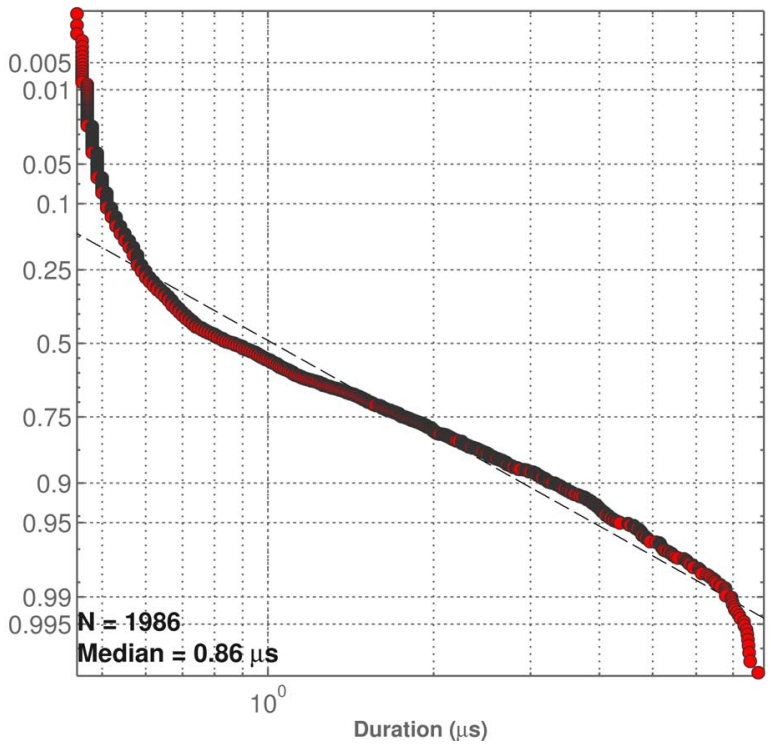

Fig. 8. Probability plot for the $t_{10-90}$ current risetime.

TABLE III

StatisticAl PARAMETERS OF CURRENT RISETIME

$t_{10-90 \%}(\mu \mathrm{s})$

\begin{tabular}{l|c|c|c|c|c|c}
\hline & & \multicolumn{6}{|c}{ Percentage Exceeding Tabulated Value } \\
\hline \multicolumn{1}{c|}{ Tower } & $\begin{array}{c}\text { Sample } \\
\text { size }\end{array}$ & $95 \%$ & $90 \%$ & $50 \%$ & $10 \%$ & $5 \%$ \\
\hline $\begin{array}{l}\text { Empire State } \\
\text { Building [21] }\end{array}$ & 82 & - & 0.3 & 1 & 5 & - \\
\hline $\begin{array}{l}\text { San Salvatore } \\
{[22]}\end{array}$ & 696 & - & 0.3 & 1 & 4 & - \\
\hline $\begin{array}{l}\text { Säntis (This } \\
\text { study) }\end{array}$ & 1986 & 0.49 & 0.51 & 0.86 & 3.29 & 4.36 \\
*) Zero-to-peak \\
Front duration: time interval between the $2 \mathrm{kA}$ point and the peak
\end{tabular}

the maximum current derivative for a total number of $N=$ 1850 events. Note that this number is smaller than the total number of measured pulses, which is 1986 . This is because the B-dot sensor cannot measure steepnesses lower than $2 \mathrm{kA} / \mu \mathrm{s}$. The highest measured value for the maximum current derivative during the period of observation is $88.9 \mathrm{kA} / \mu \mathrm{s}$. The straight line in Fig. 6 corresponds to the equivalent lognormal distribution. The median is found to be $19.9 \mathrm{kA} / \mu \mathrm{s}$.

Table I summarizes the statistical data for the maximum current derivative, in comparison with existing available data. It can be seen that the Säntis data are very similar to the data associated with the CN Tower, with the exception of the $5 \%$ value, for which a larger difference can be observed.

\section{Peak Pulse Current}

Fig. 7 presents the probability plot of the peak current for a total number of $N=1986$ events. The maximum measured value for the peak current during the period of observation is $26.5 \mathrm{kA}$ and the median is $6.4 \mathrm{kA}$. Again, it can be seen from Table II that the obtained data at Säntis seem to be closest to the

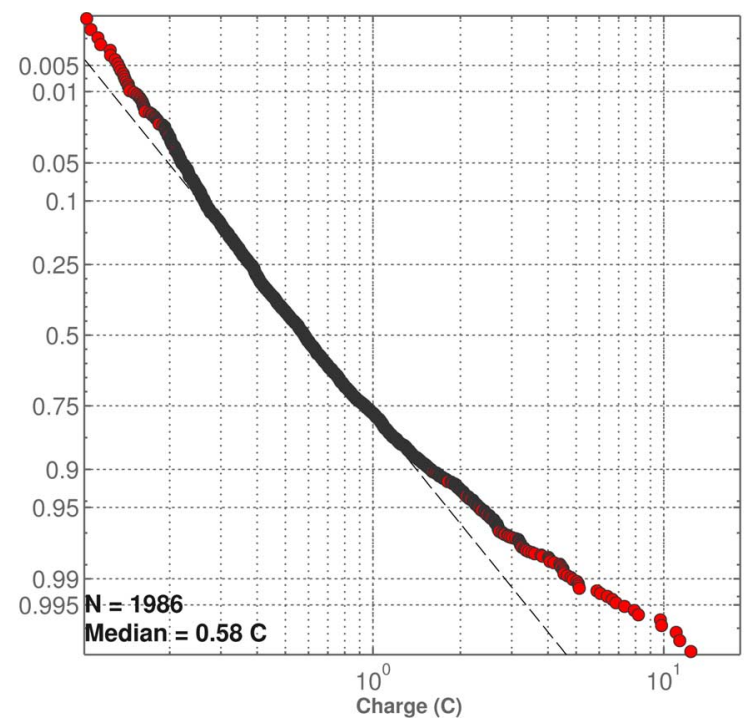

Fig. 9. Pulse charge probability plot.

TABLE IV

Statistical Parameters of Pulse Charge

Pulse Charge (C)

\begin{tabular}{c|c|c|c|c|c|c}
\hline & & \multicolumn{5}{|c}{ Percentage Exceeding Tabulated } \\
Tower & $\begin{array}{c}\text { Sample } \\
\text { size }\end{array}$ & $95 \%$ & $90 \%$ & $50 \%$ & $10 \%$ & $5 \%$ \\
\hline $\begin{array}{c}\text { Empire State } \\
\text { Building [21] }\end{array}$ & 81 & - & - & 0.15 & 1.3 & - \\
\hline $\begin{array}{c}\text { San Salvatore } \\
\text { [22] }\end{array}$ & 579 & - & 0.14 & 0.77 & 4.1 & - \\
\hline $\begin{array}{c}\text { Gaisberg } \\
\text { Tower [5] }\end{array}$ & 615 & 0.15 & 0.2 & 0.51 & 1.2 & 1.7 \\
\hline $\begin{array}{c}\text { Säntis (This } \\
\text { study) }\end{array}$ & 1986 & 0.2 & 0.3 & 0.6 & 1.6 & 2.3 \\
\hline
\end{tabular}

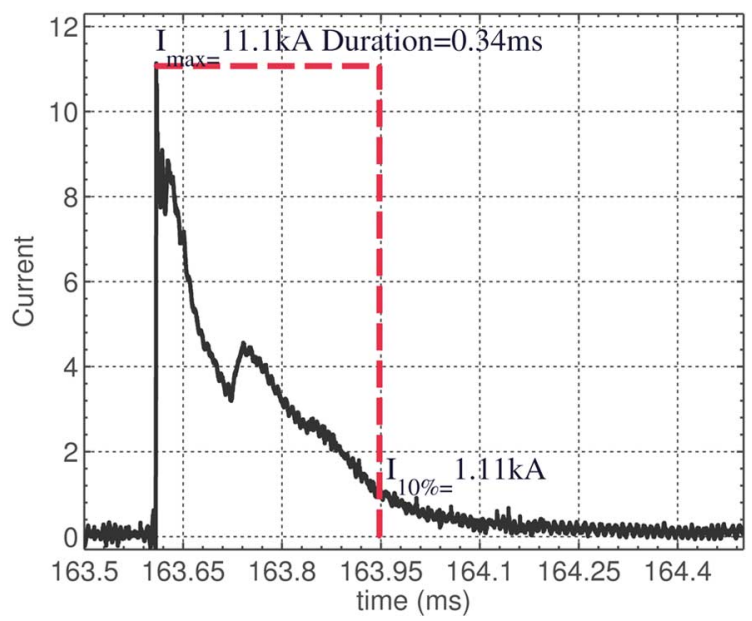

Fig. 10. Definition of the pulse duration.

data associated with the $\mathrm{CN}$ Tower and to those obtained at the Empire State Building. 


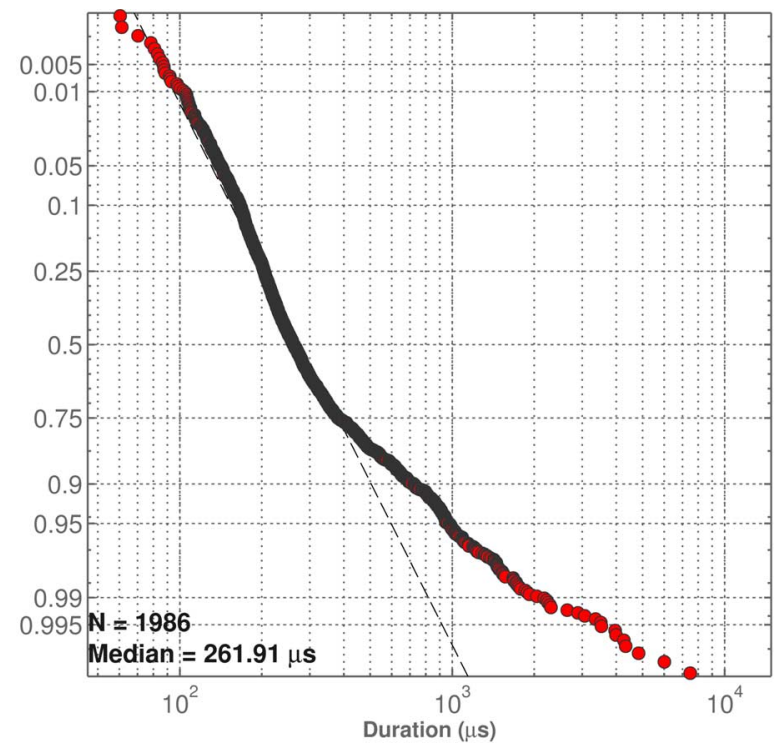

Fig. 11. Pulse duration probability plot.
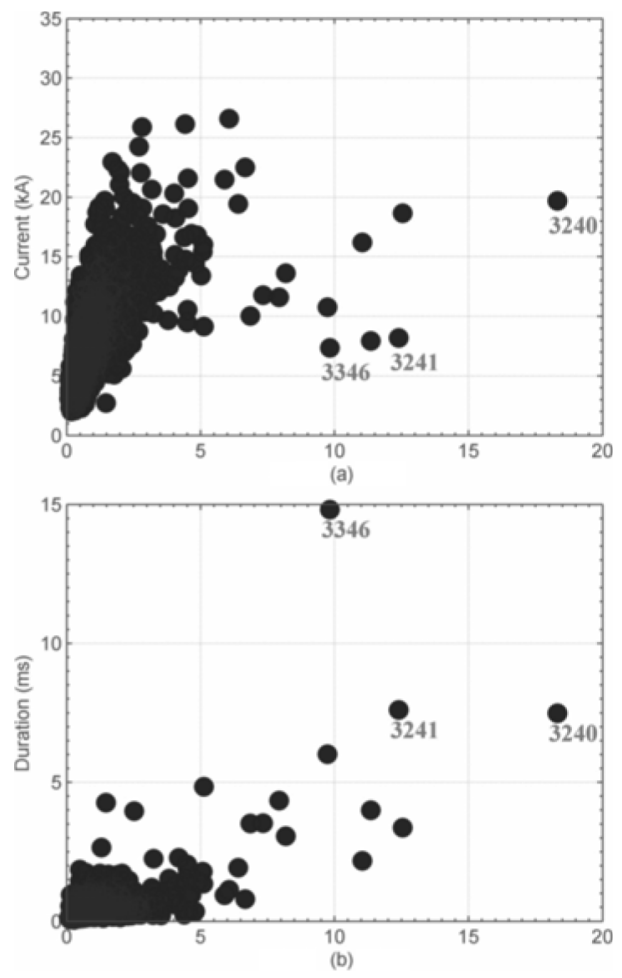

Fig. 12. Plots of (a) the current peak and (b) pulse duration versus transferred pulse charge.

\section{E. Current Risetime}

Estimates of the risetime of the measured lightning current pulses are useful in the determination of idealized lightning current waveforms that can be used in many applications such as testing, electromagnetic simulations, power system protection planning [25], bandwidth estimation, and sensor design (e.g., [26]).

Fig. 8 presents the probability plot of $t_{10-90}$ for a total of $N=1986$ events. Note that for the calculation of $t_{10-90}$, we

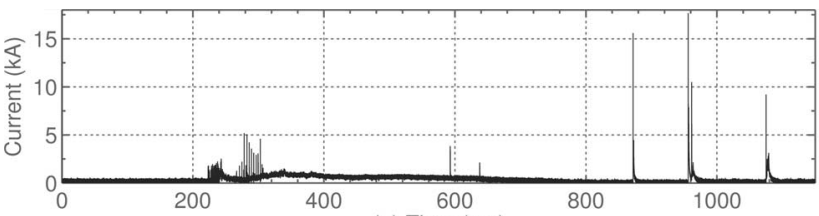

(a) Time (ms)

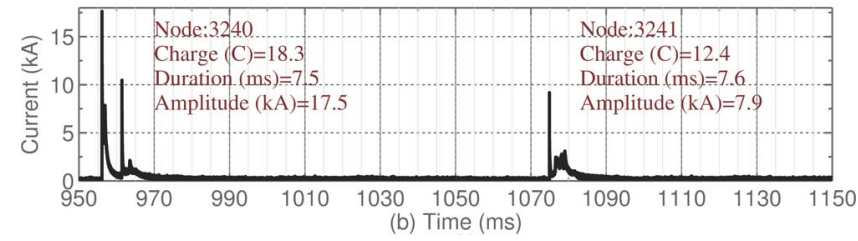

Fig. 13. Example of a current waveform associated with an upward negative flash occurred on 2011-07-13 at 17:36.26. (a) Overall flash current. (b) Details of the last two pulses (return strokes).
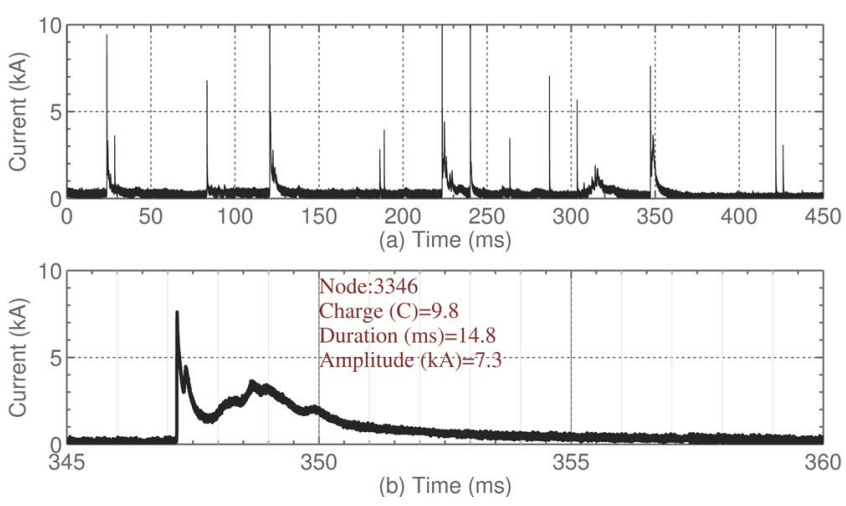

Fig. 14. Flash occurred on 2011-07-23 at 17:40.57. (a) Current for the overall flash. (b) Detail of the pulse occurred at about $350 \mathrm{~ms}$, with the longest pulse duration (labeled as 3346 in Fig. 12).

considered the overall peak and the instants when the $10 \%$ and $90 \%$ amplitudes are reached for the first time.

Table III summarizes the statistical results associated with the current risetime. In the same table, we have presented available data associated with the Monte San Salvatore Tower and the Empire State Building. Note that in these studies, different definitions were used for the risetime, as mentioned in the table.

\section{F. Pulse Charge}

Fig. 9 presents the probability plot of the transferred charge associated with each pulse for a total of $N=1986$ events. The median charge is $0.58 \mathrm{C}$.

Table IV presents a comparison of the obtained statistical data with available data in the literature. It can be seen that the obtained statistical data are very similar to those obtained recently at the Gaisberg Tower.

\section{G. Pulse Duration}

The pulse duration is defined as the time from the point in time at which the current reaches its peak to the point where the current decays to $10 \%$ of this value. This definition is illustrated in Fig. 10.

Fig. 11 presents the probability plot of the pulse duration. A total of $N=1986$ events is analyzed. 


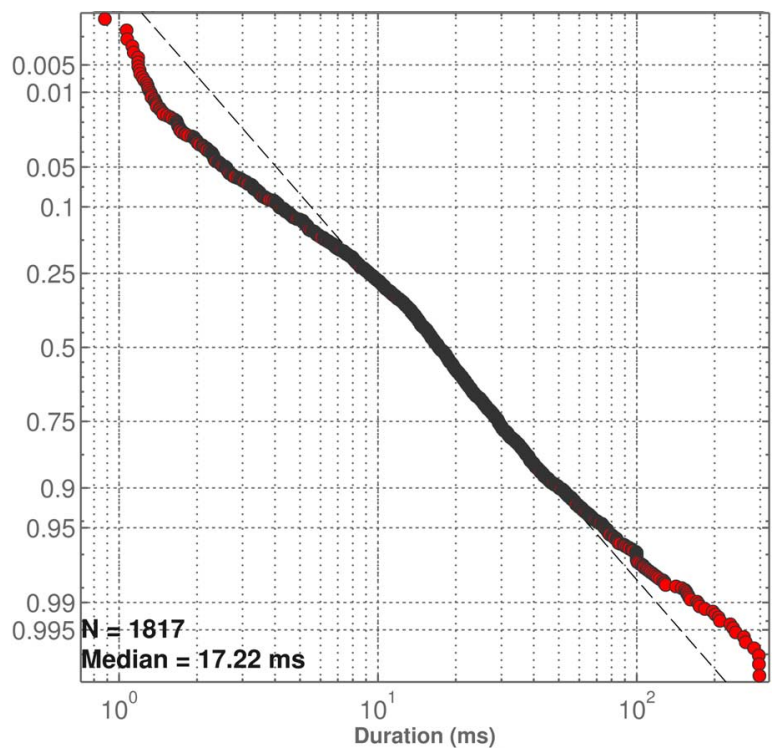

Fig. 15. Interpulse interval probability plot.

TABLE V

SuMmary of Estimated PARAMETERS For the TOTAL Flash CHARGE IN Four EventS

\begin{tabular}{c|c|c|c}
\hline Flash & $\begin{array}{c}\text { Total } \\
\text { Charge } \\
(\mathrm{C})\end{array}$ & $\begin{array}{c}\text { Total } \\
\text { Duration } \\
(\mathrm{ms})\end{array}$ & $\begin{array}{c}\text { ICC current } \\
\text { duration } \\
(\mathrm{ms})\end{array}$ \\
\hline $\begin{array}{c}\text { Flash \# } 8 \\
2010-07-26 \text { at } \\
17: 42\end{array}$ & 101 & $1100^{*}$ & 400 \\
\hline $\begin{array}{c}\text { Flash \# 70 } \\
2011-06-22 \text { at } \\
17: 21\end{array}$ & 92 & 800 & 700 \\
\hline $\begin{array}{c}\text { Flash \# } 90 \\
2011-07-13 \text { at } \\
16: 20\end{array}$ & 60 & 550 & 300 \\
\hline $\begin{array}{c}\text { Flash \# } 92 \\
2011-07-13 \text { at } \\
17: 38\end{array}$ & 181 & $1100^{*}$ & 800 \\
\hline \hline
\end{tabular}

* The maximum measurement window of the digitizers was insufficient to cover the whole flash duration

Fig. 12(a) and (b) presents scatter plots comparing the values of current peak and pulse duration as a function of transferred pulse charge. The data present a positive correlation for both figures.

Note that two pulses (labeled 3240, 3241 in the Säntis database, and visible in Fig. 12(a) and (b) labels) associated with high charges correspond to a single flash occurring on 2011-07-13 at 17:36.36 CET. The overall current measurement for this flash is presented in Fig. 13(a), and the detail of the aforementioned points in the scatter plots is depicted in Fig. 13(b). This flash is characterized by a long initial continuous current of about $400 \mathrm{~ms}$, followed by four return strokes. The overall charge transferred to ground for this flash is close to $200 \mathrm{C}$.

The event corresponding to the longest pulse, labeled 3346 in the scatter plots in Fig. 12, is presented in Fig. 14. It is characterized by a measured pulse duration of $14.8 \mathrm{~ms}$. Note that the long pulse duration is due to the presence of a continuous current following the main pulse.

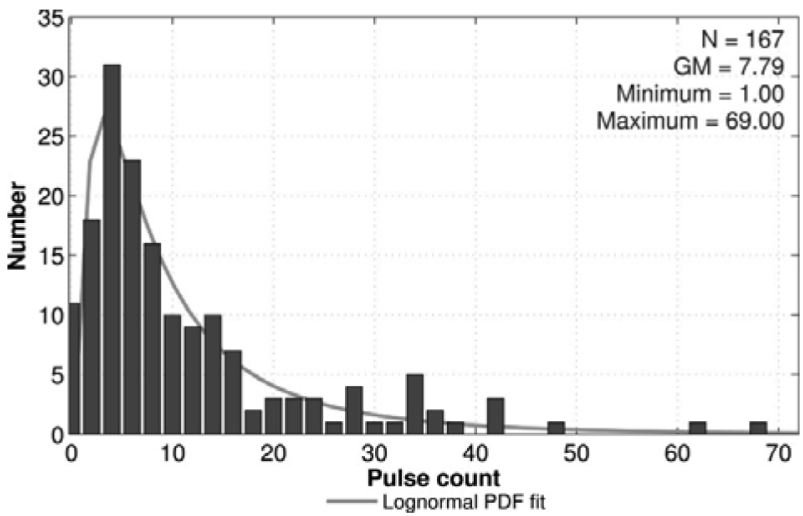

Fig. 16. Flash multiplicity histogram

TABLE VI

Summary of Statistical Parameters of Lightning CURRENTS Associated With Upward Negative Flashes Measured AT THE SäNTIS TOWER

\begin{tabular}{c|c|c|c|c|c|c}
\hline & Parameter & Sample & \multicolumn{4}{|c|}{ Percentage Exceeding Tabulated Value } \\
& size & $95 \%$ & $90 \%$ & $50 \%$ & $10 \%$ & $5 \%$ \\
\hline $\begin{array}{c}\text { Peak current } \\
\text { derivative } \\
\mathrm{kA} / \mu \mathrm{s}\end{array}$ & 1850 & 3.9 & 4.8 & 19.9 & 46.5 & 56.3 \\
\hline $\begin{array}{c}\text { Peak current } \\
\mathrm{kA}\end{array}$ & 1986 & 2.9 & 3.4 & 6.4 & 11.9 & 14.1 \\
\hline $\begin{array}{c}t_{10-90} \\
\mu \mathrm{s}\end{array}$ & 1986 & 0.49 & 0.51 & 0.86 & 3.29 & 4.36 \\
\hline $\begin{array}{c}\text { Pulse Charge } \\
\mathrm{C}\end{array}$ & 1986 & 0.2 & 0.3 & 0.6 & 1.6 & 2.3 \\
\hline $\begin{array}{c}\text { Inter-pulse } \\
\text { Interval } \\
\mathrm{ms}\end{array}$ & 1817 & 2.57 & 4.15 & 17.2 & 50.1 & 75.1 \\
\hline $\begin{array}{c}\text { Flash } \\
\text { Multiplicity } \\
\text { Count }\end{array}$ & 167 & 1 & 2.2 & 8 & 29 & 37 \\
\hline $\begin{array}{c}\text { Stroke } \\
\text { Duration } \\
\mu \mathrm{s}\end{array}$ & 1978 & 141 & 166 & 262 & 724 & 978 \\
\hline
\end{tabular}

\section{H. Interpulse Interval}

Fig. 15 presents the probability plot and histogram of the interpulse interval for a total number of 1817 intervals. The obtained value for the median $(17.2 \mathrm{~ms})$ is consistent with the value reported for the Gaisberg Tower (17.3 ms) [8].

\section{Total Flash Charge}

The noise level associated with the measurement system does not allow us to accurately characterize flashes with a relatively low initial continuous current. As a result, no statistical data will be presented for the total transferred charge associated with the flashes. Table V presents the data for the total transferred charge, total flash duration, and the ICC duration for four flashes characterized by a relatively large continuous current. It is interesting to observe that, at least in some cases, large charge transfer amounts (in excess of $50 \mathrm{C}$ ) can be associated with upward negative flashes.

All four flashes in Table $\mathrm{V}$ were measured during the convective season (July 2011 and June 2012). The main charge transfer is due to the long initial continuous current, while the individual strokes contribute marginally to the total charge. 


\section{J. Flash Multiplicity}

The histogram of the flash multiplicity (or the number of pulses per flash) is presented in Fig. 16. It presents a lognormal distribution with a median of eight pulses per flash. It is worth noting that the flash multiplicity is determined considering all the pulses of each flash satisfying the same two conditions that we used in our statistical analyses, already mentioned in Section III-A, that make them indicative of the leader/return-stroke mode of charge transfer [17], namely a risetime lower than $8 \mu \mathrm{s}$ and an amplitude superior to $2 \mathrm{kA}$.

\section{SUMmary AND CONCLUSIONS}

In this paper, we presented statistical distributions of the lightning current parameters based on the lightning current and current-derivative waveforms measured at the Säntis Tower site in 2010 and 2011. The total number of flashes analyzed in this study was 167, which include nearly 2000 pulses. The statistical distributions are associated with upward negative flashes.

In the collected measurement dataset, negative flashes were mainly concentrated in the summer months during the convective season. This distribution contrasts with the Gaisberg Tower measurements for which lightning strikes are essentially uniformly distributed over the year.

Table VI summarizes the obtained statistical data on lightning current parameters.

The obtained data were compared to and found, in general, to be consistent with published data associated with measurements obtained at other sites, the statistical values being closest to those at the CN Tower and the Empire State Building.

It is worth noting that the obtained data constitute the largest dataset on lightning current and currents derivatives associated with upward negative flashes available to this date.

\section{REFERENCES}

[1] K. Berger, R. B. Anderson, and H. Kroninger, "Parameters of lightning flashes," Electra, vol. 41, pp. 23-37, 1975.

[2] A. M. Hussein, W. Janischewskyj, J. S. Chang, V. Shostak, W. A. Chisholm, P. Dzurevych, and Z. I. Kawasaki, "Simultaneous measurement of lightning parameters for strokes to the Toronto Canadian National Tower," J. Geophys. Res., vol. 100, pp. 8853-8861, 1995.

[3] F. Heidler, J. Wiesinger, and W. Zischank, "Lightning currents measured at a telecommunication tower from 1992 to 1998," presented at the 14th Int. Zurich Symp. Electromagn. Compat., Zurich, Switzerland, 2001.

[4] S. Visacro, J. A. Soares, M. A. O. Schroeder, L. C. L. Cherchiglia, and V. J. de Sousa, "Statistical analysis of lightning current parameters: Measurements at Morro do Cachimbo Station," J. Geophys. Res., vol. 109,2004

[5] G. Diendorfer, H. Pichler, and M. Mair, "Some parameters of negative upward initiated lightning to the Gaisberg Tower (2000-2007)," IEEE Trans. Electromagn. Compat., vol. 51, no. 3, pt. 1, pp. 443-452, Aug. 2009.

[6] C. Leteinturier, C. Weidman, and J. Hamelin, "Current and electric field derivatives in triggered lightning return strokes," J. Geophys. Res., vol. 95, pp. 811-828, 1990.

[7] V. A. Rakov, M. A. Uman, K. J. Rambo, M. I. Fernandez, R. J. Fisher, G. H. Schnetzer, R. Thottappillil, A. Eybert-Berard, J. P. Berlandis, P. Lalande, A. Bonamy, P. Laroche, and A. Bondiou-Clergerie, "New insights into lightning processes gained from triggered-lightning experiments in Florida and Alabama," J. Geophys. Res.-Atmospher., vol. 103, pp. 14117-14130, Jun. 1998.
[8] V. A. Rakov, M. A. Uman, D. Wang, K. J. Rambo, D. E. Crawford, and G. H. Schnetzer, "Lightning properties from triggered-lightning experiments at Camp Blanding, Florida (1997-1999)," in Proc. 25th Int. Conf. Light. Protect., Rhodes, Greece, 2000, pp. 54-59.

[9] V. A. Rakov, R. Thottappillil, and M. A. Uman, "On the empirical formula of Willett et al. relating lightning return-stroke peak current and peak electric field," J. Geophys. Res., vol. 97, pp. 11527-11533, 1992.

[10] F. Rachidi and R. Thottappillil, "Determination of lightning currents from far electromagnetic fields," J. Geophys. Res., vol. 98, pp. 18315-18320, 1993.

[11] J. L. Bermudez, F. Rachidi, W. Janischewskyj, V. Shostak, M. Rubinstein, D. Pavanello, A. M. Hussein, J. S. Chang, C. A. Nucci, and M. Paolone, "Far-field - Current relationship based on the TL model for lightning return strokes to elevated strike objects," IEEE Trans. Electromagn. Compat., vol. 47, no. 1, pp. 146-159, Feb. 2005.

[12] C. Romero, A. Rubinstein, M. Paolone, F. Rachidi, M. Rubinstein, P. Zweiacker, and B. Daout, "Instrumentation of the Säntis Tower in Switzerland for lightning current measurements," Int. J. Plasma Environ. Sci. Technol., vol. 4, pp. 79-85, 2010.

[13] C. Romero, M. Paolone, M. Rubinstein, F. Rachidi, A. Rubinstein, G. Diendorfer, W. Schulz, B. Daout, A. Kaelin, and P. Zweiacker, "A system for the measurements of lightning currents at the Säntis Tower," Elect. Power Syst. Res. J., vol. 82, pp. 34-43, 2012.

[14] F. Rachidi, M. Rubinstein, J. Montanya, J. L. Bermudez, R. Rodriguez, G. Sola, and N. Korovkin, "A review of current issues in lightning protection of new generation wind turbine blades," IEEE Trans. Ind. Electron., vol. 55, no. 6, pp. 2489-2496, Jun. 2008.

[15] C. Romero, A. Mediano, A. Rubinstein, F. Rachidi, M. Rubinstein, M. Paolone, N. Mora, D. Pavanello, P. Zweiacker, and B. Daout, "Measurement of lightning currents using a combination of Rogowski coils and B-Dot sensors," presented at the 30th Int. Conf. Light. Protect., Cagliari, Italy, 2010.

[16] C. Romero, A. Mediano, A. Rubinstein, F. Rachidi, M. Rubinstein, A. Paolone, P. Zweiacker, N. Mora, D. Pavanello, and B. Daout, "Measurement of lightning currents using a combination of Rogowski coils and B-Dot sensors," J. Light. Res., vol. 4, pp. 71-77, 2012.

[17] D. Flache, V. A. Rakov, F. Heidler, W. Zischank, and R. Thottappillil, "Initial-stage pulses in upward lightning: Leader/return stroke versus M-component mode of charge transfer to ground," Geophys. Res. Lett., vol. 35, no. L13812, 2008.

[18] V. A. Rakov and M. A. Uman, Lightning: Physics and Effects. Cambridge, U.K.: Cambridge Univ. Press, 2003.

[19] A. Hussein, W. Janischewskyj, M. Milewski, V. Shostak, W. A. Chisholm, and J. S. Chang, "Current waveform parameters of CN Tower," J. Electrostat., vol. 60, pp. 149-162, 2004.

[20] A. M. Hussein, M. Milewski, E. Burnazovic, and W. Janischewskyj, "Current waveform characteristics of CN Tower negative and positive lightning," in Proc. X Int. Symp. Light. Protect., Curitiba, Brazil, 2009, pp. $451-456$

[21] J. H. Hagenguth and J. G. Anderson, "Lightning to the Empire State Building," AIEE Trans., vol. 71, pp. 641-649, 1952.

[22] K. Berger, "Blitzstrom-Parameter von aufwartsblitzen," Bull. Schweiz. Elektrotech. Ver., vol. 69, pp. 353-360, 1978.

[23] F. Fuchs, "Lightning currents and LEMP parameters of upward discharges measured at the Peissenberg Tower," presented at the 24th Int. Conf. Light. Protect., Birmingham, U.K., 1998.

[24] B. N. Gorin and A. V. Shkilev, "Measurements of lightning currents at the Ostankino Tower," Elektrichestvo, vol. 8, pp. 64-65, 1984.

[25] V. Cooray, Lightning Protection. London, U.K.: IET, 2010.

[26] C. E. Baum, "Maximizing frequency response of a B-Dot loop: Note 8," in Sensor and Simulation Notes, 1964.

Carlos Romero received the Ph.D. degree in electrical engineering from the Ecole Polytechnique Fédérale de Lausanne (EPFL), Lausanne, Switzerland, in 2013.

From 2003 to 2008, he was with the National University of Colombia, Bogota, Colombia, and later as Chief of Engineering of the Colombian Satellite Program. He is currently conducting a postdoctoral research project with the EMC Group, EPFL Lausanne, Switzerland, and a private company. His research interests focus on electromagnetics, lightning, and electromagnetic compatibility. 
Farhad Rachidi (M'93-SM'02-F'10) received the M.S. and Ph.D. degrees in electrical engineering from the Swiss Federal Institute of Technology, Lausanne, Switzerland, in 1986 and 1991, respectively.

He worked at the Power Systems Laboratory, Swiss Federal Institute of Technology until 1996. In 1997, he joined the Lightning Research Laboratory of the University of Toronto in Canada and from 1998 until 1999, he was with Montena EMC, Switzerland. Currently, he is a Titular Professor and the Head of the EMC Laboratory at the Swiss Federal Institute of Technology (EPFL), Lausanne, Switzerland.

Dr. Rachidi was the Vice-Chair of the European COST Action on the Physics of Lightning Flash and its Effects (2005-2009) and the Chairman of the 2008 European Electromagnetics International Symposium (EUROEM). He is presently the Editor-in-Chief of the IEEE TRANSACTIONS on Electromagnetic Compatibility, the President of the International Conference on Lightning Protection (ICLP), and the President of the Swiss National Committee of the International Union of Radio Science (URSI) $\mathrm{He}$ is the author or coauthor of more than 300 scientific papers published in reviewed journals and presented at international conferences. In 2005, he was the recipient of the IEEE Technical Achievement Award and the CIGRE Technical Committee Award. In 2006, he was awarded the Blondel Medal from the French Association of Electrical Engineering, Electronics, Information Technology and Communication (SEE).

Mario Paolone (M'07-SM'10) was born in Italy in 1973. He received the M.Sc degree (Hons.) in electrical engineering and the Ph.D. degree in electrical engineering from the University of Bologna, Bologna, Italy, in 1998 and 2002, respectively.

In 2005, he was appointed Researcher in Electric Power Systems, University of Bologna, where he was with the Power Systems Laboratory until 2011. In 2010, he received Associate Professor eligibility from the Politecnico di Milano, Milan, Italy. Currently, he is Associate Professor at the Swiss Federal Institute of Technology of Lausanne (EPFL), Lausanne, Switzerland, where he accepted the EOS Holding Chair of Distributed Electrical Systems Laboratory.

Dr. Paolone is Secretary and Member of several IEEE and CIGRÉ working groups. He was Co-Chairperson of the technical committee of the ninth edition of the International Conference of Power Systems Transients. His research interests are in the areas of smart grids, with particular reference to real-time monitoring and operation, power system protections, power systems dynamics, and power system transients with particular reference to Lightning-Electromagnetic Pulse (LEMP) interaction with electrical networks.

Marcos Rubinstein (M'84-SM'11) received the Bachelor's degree in electronics from the Universidad Simon Bolivar, Caracas, Venezuela, in 1982, and the M.Sc. and Ph.D. degrees in electrical engineering from the University of Florida, Gainesville, in 1986 and 1991, respectively.

In 1992, he joined the Swiss Federal Institute of Technology in Lausanne, where he was active in the fields of electromagnetic compatibility (EMC) and lightning in close cooperation with the former Swiss PTT. In 1995, he took a position at Swisscom, where he was involved in numerical electromagnetics and EMC in telecommunications and where he led a number of coordinated projects covering the fields of EMC and biological effects of electromagnetic radiation. In 2001, he moved to the University of Applied Sciences of Western Switzerland HES-SO, Yverdon-les-Bains, where he is currently a professor in telecommunications and a member of the IICT institute team. His current research interests include lightning, EMC in telecommunication systems, wireless technologies, and layer-2 network security. He is the author or co-author of more than 170 scientific publications in reviewed journals and international conferences.

Prof. Rubinstein is the recipient of the best Master's Thesis award from the University of Florida, he received the IEEE achievement award and he is a co-recipient of NASA's recognition for innovative technological work. He is also a senior member of the IEEE, a member of the Swiss Academy of Sciences and of the International Union of Radio Science. 